\title{
Military Regime in Pakistan and Bangladesh: A contrast in Political Processes
}

The purpose of this paper is to show that although both Pakistan and Bangladesh succumbed to military rule, the processes that led to such regimes are different from one country to another. These differing processes are related to similar as well as varying socio-economic and structural characteristics of both the societies, which are the result of historical and more recent developments. I would like to argue that neither the structural and cultural affinity nor its divergence in the case of Pakistan and Bangladesh can explain the actual political system in them, although they might have important implications for the political processes that go to shape a particular form of political organization. What is of crucial importance are the political processes that centre around inter-elite relationship in terms of cohesion and conflict for power and privileges, which the different elite groups attempt to sustain or enhance at mutual cost or vis-a-vis the masses, and which in the last instance determines the type of political system.

The data for this paper are derived from my field research in Bangladesh during 1072-73, the results of which are published in a book (Barua 1978 b), and I will depend on the extant literature for the information on Pakistan. Let us first of all delineate the similarities between the Pakistani and Bangladesh society. I shall be extremely brief, since in this short paper I cannot deal exhaustively with all the material at my disposal. Both Pakistan and Bangladesh underwent British colonial rule for a long duration. This colonial rule has left a deep imprint on them on many aspects of their existence - in administration, judiciary, education and in several other institutional aspects. Pakistan independence movement which was based on the religious ideology - Islam, for creating a state for the Muslims of the Indian sub-continent embraced both Bangladesh and West Pakistan, and Pakistan came to be constituted by the vast majority of the Muslim population in both the wings of Pakistan. More important, 25 years of Pakistani rule, particulary a decade of military ruleunder Ayub Khan shaped the politics of both the wings in administrative structure, education and economic development.

From the above one could conclude that it is natural that Bangladesh after its separation from Pakistan should undergo authoritarian rule as a legacy of all the above mentioned factors. The similarity between the two countries can be pushed to the point of saying that Sheikh Mujib was killed by army men and
Zulfikar Ali Bhutto was hanged by the Pakistani military. But this would be to overlook the vast differences that exist between the two countries in social structure, economy and culture.

Pakistani society is marked by a clear-cut horizontal cleavage between a tiny upper class consisted of landlords, top civil servants and the military elite who are related among themselves by ties of family or marriage, by economic interests and ideology (see for more details Ali 1970, Barua 1978 b). At least in the early period the Business elite was weak, there was no strong middle class, nor was there a strong trade union movement and a peasant organization to fight for the demands of the poorer masses against the privileged classes. This was more so, because no antagonism arose between the peasants and the landlords on the basis of religion, since they professed the same religion, Islam. Further, Pakistani society is characterised by diversity in ethnic, regional and linguistic composition of the population comprising Punjabis, Pathans, Sindhis and the Baluchis. Pakistan did not inherit a mature political elite. The Muslim League party which was in the vanguard of independence movement was composed of a few expatriate politicians (professionals) from the Muslim minority provinces of India and they had no power base in Pakistan. In West Pakistan the Muslim League was represented by the landlords, who constituted the largest group in the National Council of the League. They had participated in the freedom movement in the hope of achieving a country for themselves. Once Pakistan was established, the main objective of the landlords was the preservation of their privileges against the masses (Ali, op. cit.: 38-40). However, the landlords were not well-organized politically, nor had they experience in running the administration of the country. They had to depend entirely on the bureaucracy for managing the affairs of the state. As long as Mohammad Ali Jinnah lived, his stature and authority could act as a check on the bureaucracy and could contain the rivalries and conflicts within the Muslim League. But soon after his death (shortly after independence) the Muslim League had begun to disintegrate. In this situation the civil servants trained in the British colonial tradition, well-knit and cohesive, became the most effective political force in the country. The bureaucracy

Doz. Dr. Tushar K. Barua, Ethnologisches Seminar der Universität Zürich, Rämistrasse 44, 8001 Zürich 
had strong links with the landlord class, and it was drawn almost entirely from the Punjab province and being a closed group it tended to perpetuate its supremacy and safeguard its interests to the detriment of the democratic aspirations of the people.

Similarly the military elite, British-trained and drawn mainly from the Punjab, and connected with the landlord class became another most influential group in the political arena of Pakistan. The military elite came to play an important role in Pakistani politics by a combination of circumstances, I cannot go into the details in this short paper (see Ahmed Feroz, 1973 a, Ali 1970). Ever since the creation of Pakistan, fear - real or imaginery - of India and dispute over Kashmir became the main rationalizations of the growth of the Pakistani military. The army was involved with the political conflict with India, which has ever since dominated the Pakistani political scene and foreign policy. The military elite came to develop close links with the bureaucracy through the induction of several high-ranking military officers into it. Under their auspices and influence the cost of the armed forces amounted to two thirds of the central government's revenue (Myrdal 1968: 317). With the conclusion of military pact with the United States in 1954 , the military elite became powerful enough to deal with the Pentagon directly, it is said without the knowledge of the civilian government. In the words of the U.S. Department of Defence:

From a political viewpoint, U.S. military aid has strengthened Pakistan's armed services, the greatest stabilizing force in the country...

(Quoted in Feroz Ahmed 1973 b: 429)

From the above it would appear that U.S. military assistance turned the Pakistani military into the paramount political force of the country. Later on, Pakistan joined under U.S. influence the two western sponsored and supported military blocs CENTO and SEATO. The burden of Pakistan's military expenditure increased as a result thereof, which in turn strengthened the size and position of the officers corps whose ties were with the most conservative sector of the society (Myrdal op. cit.: 332).

As mentioned before, the Pakistani business elite was weak politically. Most of them were immigrants from India who settled in Karachi after partition. Because of their small size, narrow community base and lack of roots in Pakistan they could not build an effective political party of their own, nor could they assert themselves as a political force. They allied themselves with the bureaucracy which supported their enterprises and from which obviously the bureaucrats reaped benefits, and in a short while they progressed rapidly without the need to involve themselves politically. Later on, the military just like their "cousins», the administrators gave the business elite the necessary cover for their unhampered development.

In the absence of an intellectual middle class ready to identify ideologically with the masses (particulary in West Pakistan) and to mediate between the power- ful elite groups and the masses, lack of representative mass organization or student movement, the bureaucratic military elite together with the landlords constituted the national power structure of the country. The bureaucracy provided the apparatus of day to day administration, the military the organized force of coercion, and the landlords the control of the countryside, and more important, there was no serious conflict among them in terms of social origin and economic interests, and they wanted to maintain and enhance their existing privileges at the cost of more numerous sectors of population. The bureaucracy actively dominated the political scene in normal and abnormal times under the cloak of democracy: The higher civil servants and the army officiers besides being related to the conservative sector of the society by training and tradition, had no commitment to democracy of belief in politics as a means of introducing social and economic change. The unabashed scramble for spoils among politicians and their political ineptitude (Callard, 1957: 77) made the bureaucrats and the army men the virtual rulers of the country. When Ayub Khan staged a coup in 1958, the military rule signified a formalization of the relationship between the army and the bureaucracy, which had existed since the partition of the subcontient. There was no fundamental redistribution of power as much as a return to status-quo with new slogans and in the name of new ideals and radical reforms.

I would not like to argue that democracy could have eliminated all the evils of the Pakistani society. But a government based on universal suffrage meant concessions to manifestations of public opinion - withdrawl from military alliances - which would hurt the interests of the military. A government by elected repesentatives of the people could combat the influence of the bureaucracy and establish civilian control over the army. More important, rule by democratic methods meant East Pakistan's asserting its demographic strength in parliamentary elections; it amounted to submitting to the demands for regional autonomy, a fuller share for the regions in the distribution of material resources and state power, representation in the upper echelons of bureaucracy and military appointments from underprivileged regions. All these could hurt the vested interest of West Pakistanis represented by the bureaucracy, military, business and the landlords. Hamza Alavi (1973: 153) points out:

These two outstanding facts about Pakistan politics - the dominance of a bureaucratic-military oligarchy and the regional basis of challenges directed against it - are esentially two aspects of a single reality of the political situation in Pakistan which centers around the role of a bureaucraticmilitary oligarchy.

It seems to me that the reality has to include another aspect, i.e., compatibility of interests between the bureaucratic-military elite and other privileged sections of West Pakistan - the businessmen and the landlords. One should perhaps, take into account the elitistic 
conception and built-in paternalistic tradition of politics in Pakistan to explain the role of the military-bureaucratic elite. However, the end result of this kind of politics was the dismemberment of Pakistan and the creation of Bangladesh as an Independent Republic. Zulfikar Ali Bhutto, whose Pakistan People's Party (P.P.P.) won the majority of seats in West Pakistan in 1970 elections, became the Prime Minister of the P.P.P.government in December 1971. The loss of East Pakistan and the defeat suffered at the hands of the Indians produced a severe trauma among the Pakistani population. The military were sent to the barracks to lick their wounds after the shame and guilt of military defeat, and the bureaucracy was compelled to keep a low profile. Pakistan presented a semblance of democratic rule.

Bhutto, however, began to "play politics» just as the «strong men» before him did. By virtue of his party's majority in Parliament, he forced a Constitution on the country, which entitled him to absolute power, and began to identify his person with the state and the nation. By suppression of political rights, persecution of his political opponents, nepotism and corruption he attempted to establish a total grip over the state apparatus, not unlike the previous regimes. He professed an ill-defined so-called "socialism" and gave the impression of undertaking urgent social reforms, which proved to be a cloak for his strivings after power and perpetuation thereof. Bhutto's policies and particularly, his radical rhetorics aroused the aspirations of the petit-bourgeoisie, the educated lower middle class and the peasants, and seemed to threaten (perhaps, to an extent, in fact, they did) the interests of big business, landlords and the top ranks of the bureaucracy. This led to a regrouping of Bhutto's political foes into a conservative opposition known as the Pakistan National Alliance (P.N.A.). Bhutto's attempt to go for an «overkill» in the elections in March 1977 in favour of his party, and the fraudulent manipulation of the election results, which brought him victory, provoked vehement protests from the Opposition (P.N.A.) which took to the streets to demonstrate against the unfairness of the elections. The enthusiastic response of the masses to the not very much confidence-inspiring opposition compelled Bhutto to call in the army.

Bhutto's relationship with the military elite was an uneasy one. He had used it when it served his political ambitions, had courted it in order to eliminate his political opponents, had kept himself aloof from its excesses by maintaining that he was a "man of the people». Inspite of all this, the military were prepared to tolerate Bhutto's failings, but when they found that he was cornered from all sides, and besides, he accused the Americans of complicity in the revolt aiming to overthrow him, the military could no longer keep silent. The military were not at all anxious to weaken the traditional close relationship with the Americans from whom they derived most of their resources and concomitant power and privileges. With the most modern weapons at their disposal, having long been spoilt by the politics of clever manoeuvering, the Pakistani military could hardly miss the chance of stepping into the shoes of politicians, arguing that they could no longer stand by, as political polarization disrupted the country's peace and unity, the self-same argument they had used before.

Let us now examine the political processes that led to military rule in Bangladesh*. As we have stated earlier Bangladesh is very different from Pakistan in social structure, economy and culture. The Bengalis are unlike the Pakistanis in their ethnic, cultural and linguistic characteristics, besides being separated from them by a great spatial distance. They are a homogeneous population $90 \%$ of whom are Muslims. What is more important is that Bangladesh did not have a top upper class separated by a deep horizontal cleavage from the masses. It had neither a landlord class nor a business elite (all of them were Hindus and left for India after partition) nor had the Bengalis access to the higher ranks of the bureaucracy, the military of the business elite, since they were denied any such access by the west Pakistanis. Immediately after independence the latter stepped into the shoes of the Hindu elite in business and administration and East Pakistan was virtually reduced to a colony (see Ahmed Feroz 1973 b: 421-425).

But Bangladesh had an educated middle class, a politically active student community, a tradition of trade union and peasant movement against the privileged classes. From time to time various politically articulate groups and parties which identified ideologically with the masses revolted against the Pakistani regime for democracy, parliamentary elections, and regional autonomy and other democratic rights of the people. In the later phase of Pakistani rule there developed in Bangladesh a mass political party (besides others) under the leadership of semi-urbanized rural elite, the main representative of which was Sheikh Mujib. Besides, the Bangladesh military were the product of the liberation war, they did not inherit the tradition, discipline and the organization characteristic of Pakistani military, nor were their elite cadres similar to those of Pakistan in socio-economic origin and education. In the above context one could assume that Bangladesh unlike Pakistan had some of the important prerequisites for experimenting with democracy. If we accept Shil's (1962) arguments for the role of the military in the political development of the New States, then it would seem that Bangladesh presented a situation which would negate such a role, and fulfilled conditions (obviously with some limitations) which would warrant a democratic regime. The Bengalis vehemently fought for political freedom and democracy against the Pakistani regime and time and again professed these ideals against serious odds for long period under the Pakistani rule. It is an appropriate question then, to ask what triggered the military to assume political power?

*I have drawn heavily for this section from my previous work (Barua 1978 a). 
I am inclined to think that the key to the answer lies in the processes of inter-elite relationship rather than in the general character of the Bengali society. I have shown elsewhere (Barua 1978 b) that all the underprivileged elite groups of East Pakistan got united in the platform of the Awami League under Sheikh Mujib to fight against the Pakistani military-bureaucratic elite, since the latter discriminated against them in the name of race, language and culture. Their unity derived from the fact that they faced a common enemy, the West Pakistani elite, and therefore, mobilized the masses in their favour. The result was the creation of Bangladesh as an independent state. But under the facade of unity there existed discrepancies between the different elite groups in terms of values, goals and interests which came to the surface immediately after independence.

The Awami League represented the interests of the lower middle "class" and rural elite, and backed by mass support wanted to monopolize the positions of power left vacant by the West Pakistani elite. But the AL (Awami League) political elite was heterogeneous, it had no common ideology or program, and was united under Sheikh Mujib and his party by a common desire to share the spoils of office, without much regard for the interests of the other contending elite. Its pseudo-socialism, «Mujib bad» was ill-defined and was used to win popularity and legitimize the ploitical elite's access to power and to enhance it.

The main contender to AL's power was the bureaucracy, the components of which were better organized and educated, and also socio-economically better situated. The Pakistani ruling elite had to yield to the pressure of the Bengali movement in previous decade, and had to concede to some of the demands of the movement for a fair share of jobs and promotion. As a result in the 1960s the provincial administration in East Pakistan was almost exclusively staffed by the Bengali civil servants at all levels (Alavi, op. cit.: 168). The AL political elite began to attack the latter of having been the collaborators of the previous regime and accused them of having a "Pakistani mentality». The administrative elite who considered themselves as social superiors (most of them were sons of middle class professionals) to the politicians developed little sympathy for them and began to work under them under duress: loss of jobs, security and promotion. During the latter part of Ayub's regime a Bengali bourgeoisie was developing in collaboration with the West Pakistani big business as subordinate partners (ibid: 169-170). The Awami League's programme of socialism and nationalization of private enterprises hurt the interests of the rising bourgeoisie and their aspirations to take over the mantle of West Pakistani big business. Obviously, a conflict developed between the political elite and the Bengali business, particulary so, because nationalization programmes were used as a cloak to foster the interests of the top Awami League cadres and followers. The AL political elite created a huge planning machinery and enlisted a number of middle class professional intellectuals to frame plans for the solution of socio-economic problems of Bangladesh. However, the Planning Commission and its plans were meant to serve them as a source of legitimacy, rather than as a means to overcome the serious economic problems facing the country. On the other hand, the bureaucracy resented the planners as «superbureaucrats» who invaded the sphere of its decision making power and challenged its administrative role.

The political elite had little experience of administration or of running the government (the West Pakistani ruling elite gave them little chance and condemned them to opposition) and their lack of experience combined with deep corruption among the AL cadres at different levels led the political situation from bad to worse. In order to suppress political opposition and criticism from all sides, the political elite instituted a new Defence Force (Rakkhi Bahini) which became the armed organ of the AL party and government. The Awami League elite forced a constitution on the country by virtue of its overwhelming majority in the Parliament, and declared elections in March 1973, which were any thing but fair. The arrogance and brutality with which the opponents of the regime came to be handled created a situation of extreme tension in Bangladesh. The army, which remained neutral till then, looked with suspicion at the new armed force which vied with it in terms of resources and outfit (see Barua 1978 b, ch XIII). The political elite, in the meantime, became more and more discredited in the face of failures to improve the political and economic situation of the country, and had to call in the army, on several occasions, to check corruption, to control smuggling along the borders and to establish law and order. The top officers of the military in all these operations came face to face with the rampant corruption in which the political elite and its supporters were involved, and became disenchanted with them for their ineptitude. Although similar to the political elite in socio-economic origin, the army officers were better organized and task-oriented, and in these respects were closer to the bureaucracy than any other elite group. When Sheikh Mujib was murdered, the army with its organization, and more important, with the instruments of coercion at their disposal, along with the bureaucracy, took over the political power in Bangladesh.

In the above pages I have brought the two sets of data into relationship by directing attention to the nature of political processes in the two contrasted types of society. Although the analysis of social structure is basic to the understanding of the political developments in any country, static structural analysis alone does not help us to explain why a particular political system takes the form it does. Nicholas (1968: 248) states:

Vertical political cleavages are characteristic of the ideal unstratified society, while horizontal clea- 
vages are characteristic of the ideal statified society. This is a statement about political systems in the most general and abstract terms; it is applicable to the analysis of political systems in societies of all scales at all times.

Certainly identification of cleavages both vertical and horizontal, is one way to define the character of competition for power, particularly in small scale societies where such cleavages are clear cut along caste, religious, linguistic, ethnic and regional lines. But this alone does not help us to explain the political system especially in the developing nation-states. As I have shown, in Pakistan there are clear-cut horizontal cleavages between the top upper class and the masses, and there are also vertical ones along linguistic, ethnic and regional lines. In Bangladesh, however, there are no such sharp horizontal cleavages between the educated middle class and the masses or vertical cleavages among the population. To be sure, the educated middle class and the rural elites are separated from the masses by their education and wealth, but these differences are not accentuated as in the case of Pakistan; there is a certain amount of mobility among and between the elites and the masses.

In this paper I have sought to distinguish the form the political processes have taken around inter-elite relationship in Pakistan and Bangladesh, and tried to show how the varying and common features of their social systems are related to the differences in the nature of political processes and the similarity in their political system. To be sure, structural cleavages have important implications for the political processes, but they are only one element in the competition for power. As Epstein (1968: 55) observes:

Equally relevant to a discussion of the power structure,... are such considerations as the goals which are available to men who aspire to power, and the kind of resources, human or otherwise, over which access to power gives control.

In a similar vein, I would like to argue that the particular form a political system takes can be explained by the processes of interaction between the different elite groups in terms of cohesion and conflict, the goals to which they aspire, and the resources each group commands and use to achieve them, irrespective or in spite of the cleavages that characterize a particular society. In other words the analysis of inter-elite relationship may be an important clue to the understanding of political change in the developing countries.

\section{Zusammenfassung}

Der Verfasser geht der Frage nach, warum die politische Entwicklung im West- und im Ostteil des 1947 gegründeten Pakistan und in dessen Nachfolgestaaten Pakistan und Bangladesh bei einigen Gemeinsamkeiten so unterschiedliche Wege genommen hat. Diese Entwicklungen werden skizziert und die Positionen der Schichten sowie deren jeweilige Distanzen gekennzeichnet. Es wird gezeigt, daß weder die Berücksichtigung der kulturellen Hintergründe noch das Modell der vertikal oder horizontal gestaffelten Gesellschaften noch ein Vorrang, der den kontrollierbaren Ressourcen gegeben wird, ausreicht, um die unterschiedliche Entwicklung zu erklären. Es muss vielmehr notwendigerweise das gesamte Netz inter-elitärer Beziehungen berücksichtigt werden, welches aufgrund komplexer historischer Abläufe in den beiden Ländern verschiedene Formen annahm und zu verschiedener Politik führte.

\section{References}

AHMED FEROZ., 1973a: «Structure and contradiclion in Pakistan", in: Imperialism and Revolution in South Asia. Ed. by K. Gough and H. P. Sharma. London: Monthly Review Press. pp 174-200.

AHMED FEROZ., 1973 b: "The structural Matrix of the Struggle in Bangladesh» in: same as above. pp 419-448.

ALAVI HamZA., 1973: "The state in Postcolonial Societies: Pakistan and Bangladesh", in: as above. pp 145173.

ALI T., 1970: Pakistan: Military Rule or People's Power. London: Jonathan Cape, 30 Bedford Square.

BARUA TUSHAR K., 1978a: "The role of the Military in South Asia with special reference to India and Pakistan", in: Asie du Sud: Traditions et changements. Eds. M. Gaborieau et A. Thorner. Paris: Editions du Centre National de la Recherche Scientifique.

BARUA TUSHAR K., 1978b: Political Elite in Bangladesh: A Socio-anthropological and Historical analysis of the processes of theirformation. Bern: Peter Lang Publishers Ltd.

Callard Keith., 1957: Pakistan: A political Study. New York: Macmillan Company.

EPSTEIN A. L., 1969: «Power, Politics and Leadership: Some Central African and Melanesian Contrast», in: Local Level Politcs. Ed. by M. J. Swartz. London: University of London Press. pp 53-68.

MYrdal G., 1968: Asian Drama: An Inquiny into the Poverty of Nations. Vol. I. New York: Pantheon.

NICHOLAS RALPH W., 1968: «Structures of politics in the Villages of Southern Asia", in: Structure and Change in Indian Society. Ed. by Milton Singer and Bernard S. Cohn. Viking Fund Publications in Anthropology, No 47, New York.

SHILS E., 1972: "The military in the Political Development of the New States", in: The role of the Military in underdeveloped Countries. Ed. by John. J. Johnson N. J.: Princeton University Press. pp 7-68. 